\title{
Aggressiveness of Conidiobolus obscurus against the Pea Aphid: Influence of Cuticular Extracts on Ballistospore Germination of Aggressive and Non-aggressive Strains
}

\author{
By JEAN-PAUL LATGÉ, *† LAURA SAMPEDRO, PAUL BREY \\ AND MICHEL DIAQUIN
}

Unité de Lutte biologique contre les Insectes, Institut Pasteur, 25 rue du Dr Roux, 75724 Paris Cedex 15, France

(Received 23 January 1987)

\begin{abstract}
Cuticular extracts of Acyrthosiphon pisum, the pea aphid, stimulated the formation of germ-tubes of ballistospores of aggressive strains of Conidiobolus obscurus, but showed no influence on those of non-aggressive strains. Aggressive strains were separated into two groups: $(a)$ those stimulated by both (i) water- or alcohol-soluble cuticular extracts originating from honeydew and (ii) lipidic extracts of the cuticle, and $(b)$ those stimulated by (ii) only. The hydrocarbon and polar fractions of the cuticular lipids were the most active. These results obtained with $C$. obscurus are compared to the effect of cuticular compounds on spore germination in other entomopathogenic fungi.
\end{abstract}

\section{INTRODUCTION}

One of the first critical events in the establishment of a fungal infection in arthropods is the germination of the spore on the host cuticle. Spore germination is influenced by the environmental conditions found on the cuticular surface. Temperature and humidity have been generally considered as the most important factors for controlling the germination of fungal spores (Gottlieb, 1978). However, in fungi pathogenic to plants and animals, nutrients present on the surface of the host also influence the development of the fungal propagules and are consequently a key factor in the establishment of the pathogenicity of a fungal strain (Cole \& Nozawa, 1981; Wynn, 1981). Nutrients present on the host surface may be endogenous to the cuticle or exogenously deposited by leachates from aerial surfaces, host exudates or arthropod faecal and regurgitated material.

Ballistospores of the entomogenous Entomophthorales which make contact with an insect can interact in one of three ways: they may form germ-tubes able to infect the insect; they can resporulate and form secondary spores which will be forcibly discharged; they may not germinate and their survival will depend on the environmental conditions and their own nutritive resources. The aggressiveness of Conidiobolus obscurus (Zygomycetes : Entomophthorales) has been correlated to the germination capabilities of this fungus: the aggressive $\left(A^{+}\right)$strains have more spores producing germ-tubes on the cuticle of the pea aphid than the non-aggressive ones $\left(\mathrm{A}^{-}\right)$(Latgé et al., 1982). However, the germination of these strains in vitro was variable, with some of the $\mathrm{A}^{+}$strains being unable to form germ-tubes under the different experimental conditions tested (Sampedro et al., 1984). These results suggested that some aphid cuticular components may have a specific effect on conidial germination of $C$. obscurus. The aim of this study was to examine the influence of the nutritional conditions of the aphid cuticle on conidial germination.

† Present address: Unité de Mycologie, Institut Pasteur, 25 rue du Dr Roux, 75724 Paris Cedex 15, France. 


\section{METHODS}

Fungal and aphid strains. The origin of aggressive $\left(542^{+}\right.$or $722^{+}, 637^{+}, 879^{+}$and $\left.940^{+}\right)$and non-aggressive $\left(280^{-}\right.$, $313^{-}$and $455^{-}$) strains of $C$. obscurus towards the pea aphid has been previously reported (Latgé \& Boucias, 1984). The isolates were cultured on an egg-yolk agar medium (Sampedro et al., 1984). Pea aphids, Acyrthosiphon pisum of clone B as defined by Papierok \& Wilding (1979), were reared on bean plants at $18^{\circ} \mathrm{C}$ under constant light.

Isolation and fractionation of cuticular extracts. Laboratory-reared aphids of all developmental stages were collected in plastic boxes and inactivated by storage at $-20^{\circ} \mathrm{C}$ for $5-10 \mathrm{~min}$. Some aphid batches were stored at $-20^{\circ} \mathrm{C}$. Aphids ( $20 \mathrm{~g}$ fresh weight samples) were submerged for $30 \mathrm{~s}$ to $5 \mathrm{~min}$ at $10^{\circ} \mathrm{C}$ into $500-1000 \mathrm{ml}$ of various solutions: water, $50 \%(\mathrm{v} / \mathrm{v})$ ethanol, chloroform $/$ methanol $(2: 1 \mathrm{v} / \mathrm{v})$. The crude extracts were recovered by filtration and concentrated at $40{ }^{\circ} \mathrm{C}$ under vacuum in a rotary evaporator.

The desiccated chloroform/methanol extract was dissolved in 150-200 ml of a mixture of chloroform/methanol/ water $(8: 4: 3$ by vol.). The upper phase with the polar material and the lower phase containing total lipids were concentrated in a rotary evaporator and stored respectively in water and hexane at $-20^{\circ} \mathrm{C}$. The lipid extract was fractionated in a silicic acid column $\left(10 \mathrm{~g}\right.$ silicic acid pre-heated at $110^{\circ} \mathrm{C}$ for $12 \mathrm{~h}$ for $10-15 \mathrm{mg}$ lipid extract poured as a hexane solution). The lipid fractions were eluted with $50 \mathrm{ml}$ of the following solvents: hexane (fraction I), $50 \%(\mathrm{v} / \mathrm{v})$ diethyl ether/hexane (fraction II), $2 \%(\mathrm{v} / \mathrm{v})$ methanol/diethyl ether (fraction III), $2 \%$ (v/v) glacial acetic acid/diethyl ether (fraction IV) (Baker et al., 1979). Quantitative extraction of residual lipids on the column was done for $24 \mathrm{~h}$ successively with $100 \mathrm{ml}$ chloroform (fraction V) and $100 \mathrm{ml}$ methanol (fraction VI). All these fractions were concentrated in a rotary evaporator and their composition was checked by TLC on silica gel (Merck $60)$ plates developed in hexane/diethyl ether/acetic acid $(80: 20: 1$ by vol.) and charred with $70 \%$ (v/v) perchloric acid for $10 \mathrm{~min}$ at $100{ }^{\circ} \mathrm{C}$. Further purification of fractions II-V was done using preparative silica gel TLC with the same solvent system. The bands corresponding to these components were scraped into flasks and extracted overnight with the corresponding solvents used in the silicic acid column chromatography. All extracts were stored at $-20^{\circ} \mathrm{C}$.

The methanolic extract $\left(5 \mathrm{mg} \mathrm{m}^{-1}\right)$ was fractionated using an ultrafiltration cell (Diaflo-Amicon) at $3 \mathrm{~atm}$ $(304 \mathrm{kPa})$ under a nitrogen flow and constant agitation. Five fractions were separated according to their molecular weight $\left(M_{\mathrm{r}}\right)$ : (1) >10000, (2) 5000-10000, (3) 1000-5000, (4) 500-1000, (5) $\leqslant 500$.

Recovery of water-soluble non-structural components of the cuticle. Anal secretions (honeydew) of the aphid, composed mainly of free sugars and amino acids, often contaminated the cuticle of these insects. Honeydew was recovered as previously described (Brey et al., 1985) and stored as an aqueous solution at $-20^{\circ} \mathrm{C}$.

Assay of conidial germination. Microscope slides were covered with $3.5 \mathrm{ml} 1$ or $2 \%(\mathrm{w} / \mathrm{v}$ ) agar (Difco) containing $20 \mathrm{~mm}$-sodium-potassium phosphate buffer, $\mathrm{pH} 6.2$ or $8 \cdot 0$. These two $\mathrm{pH}$ values were chosen because $6 \cdot 2$ was the $\mathrm{pH}$ of the aphid cuticular surface and induced mainly secondary conidia in vitro; in contrast, basic $\mathrm{pH}(8 \cdot 0)$ promoted germ-tube formation (Sampedro et al., 1984). Alcoholic and aqueous cuticular extracts and the honeydew fractions were directly incorporated into the agar at concentrations ranging from 0.5 to $25 \cdot 0 \mathrm{mg}$ per ml agar medium. One or several successive $25 \mu \mathrm{l}$ drops of the lipidic fractions at concentrations ranging from 2.5 to $50 \mathrm{mg} \mathrm{ml}^{-1}$ (corresponding to a final range of lipid concentration of $0.12-1.0 \mathrm{mg} \mathrm{cm}^{-2}$ ) were deposited as a spot on the surface of the agar. Germination was tested after evaporation of the solvents $\left(15 \mathrm{~min}\right.$ at $\left.20^{\circ} \mathrm{C}\right)$.

Ballistospores produced from scraped mycelial thalli (Sampedro et al., 1984) were projected onto the test slides and incubated at $20^{\circ} \mathrm{C}$ in darkness. Depending on the strain, spores germinated $2-4 \mathrm{~h}$ after being discharged on the agar. They produced germ-tubes (GT) or secondary spores (C2) as previously defined (Sampedro et al., 1984). Two ratios were estimated: the total percentage of germinating spores, $[(\mathrm{GT}+\mathrm{C} 2) /(\mathrm{GT}+\mathrm{C} 2+\mathrm{UG})] \times 100$, and the percentage of spores forming germ-tubes, $[\mathrm{GT} /(\mathrm{GT}+\mathrm{C} 2+\mathrm{UG})] \times 100$, where $\mathrm{UG}=$ ungerminated spores. To avoid any confusion between a true germ-tube and a young conidiophore which had not yet formed a secondary spore, counts for estimating the percentage of germ-tubes were made after 6-10 h of incubation (depending on the strain). One hundred conidia were counted on each slide, with four to eight replicates per experiment. The germtube length was measured on 20 conidia per slide. Results were analysed statistically after an angular transformation of the percentage of germination $(p)$ by a one- or two-way variance analysis. They are expressed as $\arcsin \sqrt{p} \pm \mathrm{SD}$.

\section{RESULTS}

\section{Influence of polar extracts on total germination}

Water-soluble cuticular extracts at a concentration of $0.5-5.0 \mathrm{mg} \mathrm{m}^{-1}$ stimulated the total germination of strains $542^{+}$and $879^{+}$but showed no influence on strains $637^{+}, 940^{+}, 313^{-}$and $455^{-}$. A dose of $25 \mathrm{mg} \mathrm{ml}^{-1}$ inhibited the germination of all strains tested. Comparable results were obtained for all these strains at $\mathrm{pH} 6.2$ and 8.0 (Fig. 1). The $50 \%(\mathrm{v} / \mathrm{v}$ ) ethanol extract, the methanolic fraction of the chloroform/methanol cuticular extract, and an aqueous solution of 


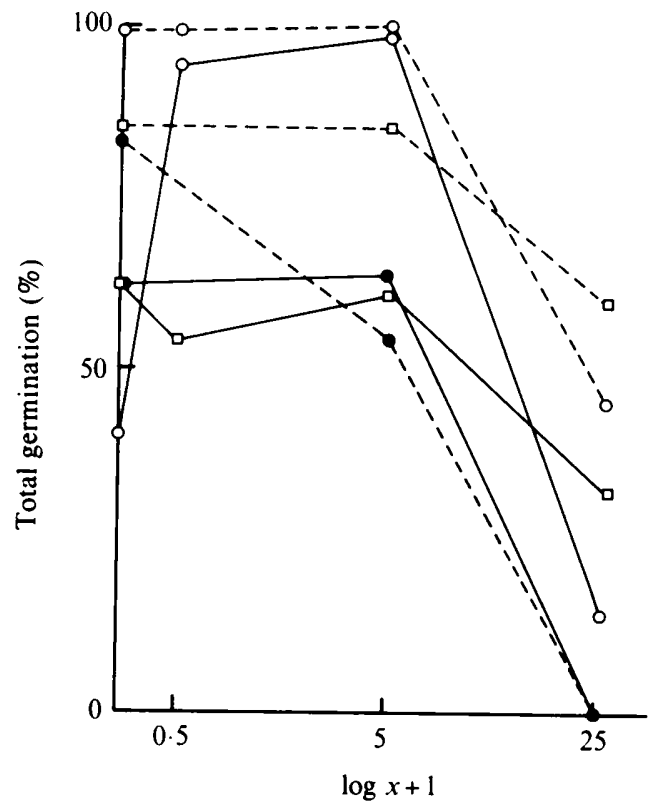

Fig. 1. Influence of polar aphid cuticular components extracted by water on total germination of strains $542^{+}(\mathrm{O}), 940^{+}(\square)$ and $455^{-}(O)$ at $\mathrm{pH} 6.2$ (full line) and at pH 8.0 (dotted line). $x$, Initial concentration of the cuticular extract $\left(\mathrm{mg} \mathrm{ml}^{-1}\right)$.

the honeydew stimulated the germination of strains $542^{+}$and $879^{+}$, at $\mathrm{pH} 6 \cdot 2$, but did not influence strains $940^{+}, 637^{+}, 313^{-}$and $280^{-}$(Table 1 ).

In the methanolic extract, the fraction containing the low $-M_{\mathrm{r}}$ components $(\leqslant 500)$ was the only one active on strain 542 (Fig. 2).

Influence of polar extracts on germ-tube formation

Strains $637^{+}, 940^{+}, 313^{-}$and $455^{-}$rarely produced germ-tubes in the presence of the four different polar extracts tested at concentrations up to $25 \mathrm{mg} \mathrm{ml}^{-1}$ at $\mathrm{pH} 6 \cdot 2$ and $8 \cdot 0$. However, germ-tube formation never attained $1 \%$. Conversely, at $\mathrm{pH} 6 \cdot 2$, the formation and growth of germ-tubes of strains 542 and 879 was stimulated by the polar cuticular extracts and the honeydew (Table 2). Between 0.5 and $5.0 \mathrm{mg} \mathrm{ml}^{-1}$, the concentration of the extract did not influence germ-tube formation and growth (Table 2); however, a concentration of $25 \mathrm{mg} \mathrm{ml}^{-1}$ strongly reduced the formation of germ-tubes. The method of extraction of the polar extract did not influence the effect on germ-tube production (Table 2). Extraction time did not influence either of the results, similar data being obtained with fractions collected after $0 \cdot 5,5$ and 30 min of extraction. The low- $M_{\mathrm{r}}$ fraction was the only one able to stimulate the formation of germtubes (Fig. 2).

The ease of extraction of the fractions and the positive effect of the low $-M_{\mathrm{r}}$ components and of the honeydew strongly suggest that the components extracted by water and alcohol are probably non-structural metabolites originating mainly from the honeydew.

\section{Influence of lipidic extracts on total germination}

Cuticular lipid extracts did not influence the percentage germination of strains $542^{+}, 722^{+}$and $879^{+}$but inhibited the total percentage of germination of strains $940^{+}, 637^{+}, 313^{-}$and $455^{-}$ (Table 3). However, the lipid extracts only delayed the germination of these strains, since the same percentage of germination was observed 8-10 h after discharge in the control and treated samples (data not shown). 


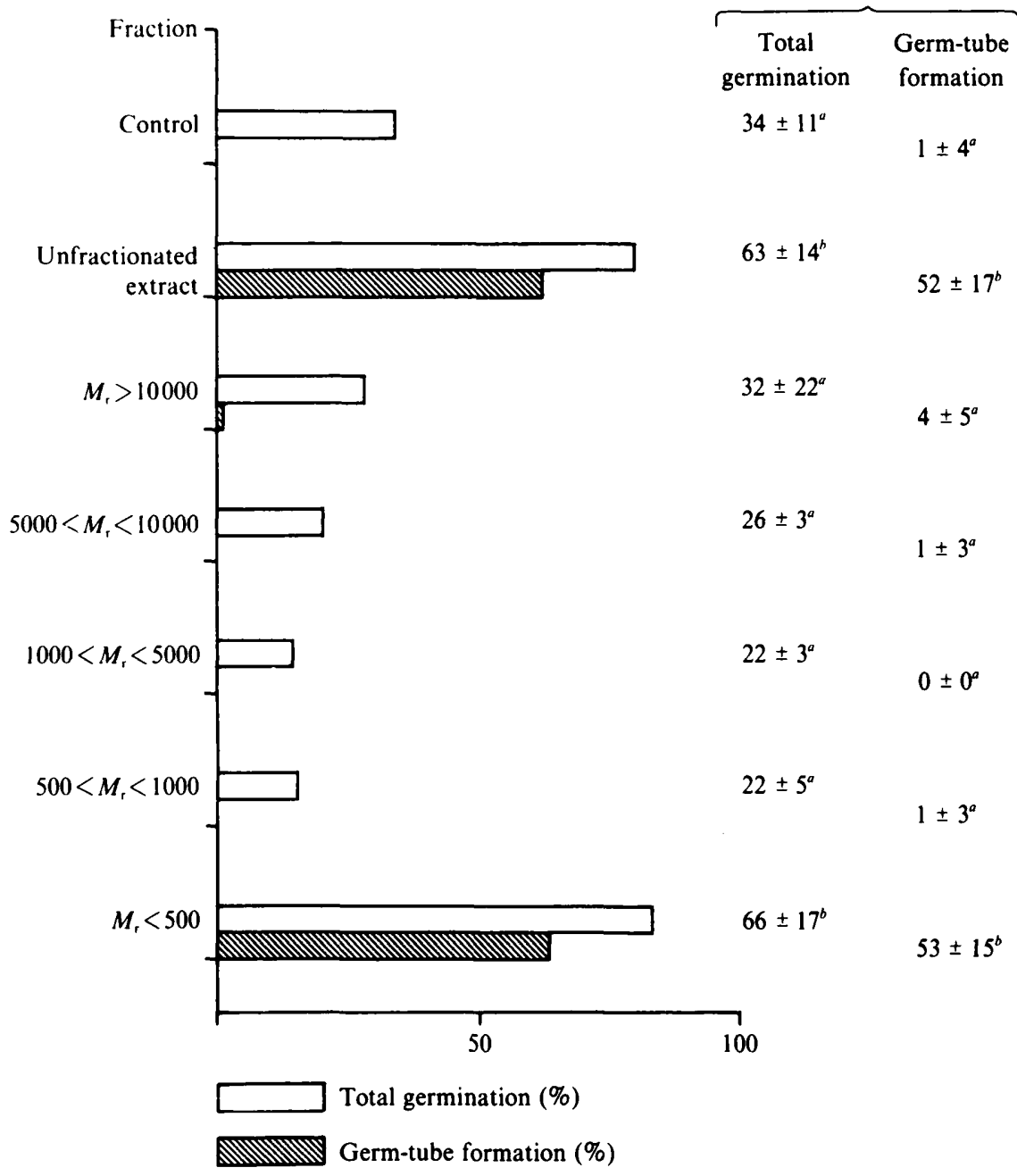

Fig. 2. Influence of fractions of different $M_{\mathrm{r}}$ of the methanolic fraction of the chloroform/methanol extract on the total germination and germ-tube formation of strain $542^{+}$of $C$. obscurus. The results are expressed as the mean percentage, $p$. The statistical analysis is made on an angular transformation of $p$ expressed as arcsin $\sqrt{p} \pm$ SD. Percentages followed by the same letter are not significantly different using Duncan's multiple range test $(P=0.05)$.

\section{Influence of lipidic extracts on germ-tube formation}

Cuticular lipids promoted the formation of germ-tubes of strains $940^{+}$and $637^{+}$(which were not stimulated by polar extracts) at pH 6.2 and 8.0: 14-90\% of spores produced germ-tubes on the slides covered by the cuticular lipid extracts while no germ-tubes were produced in the control. These lipidic extracts also stimulated the formation of germ-tubes of strain $879^{+}$, which was stimulated by the polar extracts (Table 4). Lipid extracts were also able to counter-influence the effect of physical factors on the mode of germination. For example, at $\mathrm{pH} 6 \cdot 2$, all spores of strain $722^{+}$produced secondary spores. In the presence of lipids, at least $25 \%$ of these spores formed germ-tubes (data not shown). In contrast, the cuticular lipids were not able to provoke the formation of germ-tubes of the $\mathrm{A}^{-}$strains tested $\left(280^{-}, 313^{-}, 455^{-}\right)$at $\mathrm{pH} 6 \cdot 2$ or 8.0 . A basic $\mathrm{pH}(8.0)$ and a high concentration of lipidic extract $\left(5.0 \mathrm{mg} \mathrm{cm}^{-2}\right)$ were the most favourable conditions for inducing the formation of germ-tubes of strains $637^{+}$and $940^{+}$(Table 4). A concentration less than or equal to $0.1 \mathrm{mg} \mathrm{cm}^{-2}$ did not stimulate the formation of germ-tubes (data not shown). 
ธิ

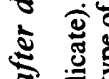

今

+1 递定

$\pm$

จิ

溶 8

5 o

党

ช

ธे ㅎํㅇ

\&

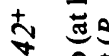

it के

卷 +1 需

5

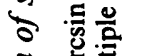

ฐ

I.

空

ฐ

5

§

5 는응

气

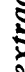

s

\& 5

\&

旅

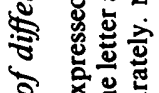

อ

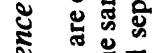

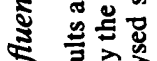

ह

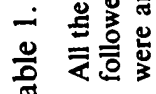

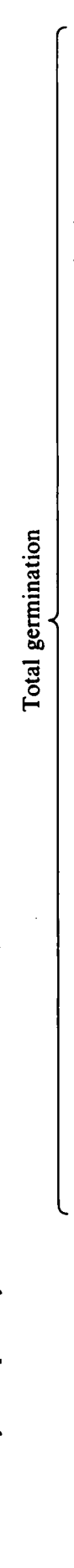

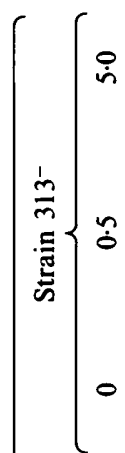

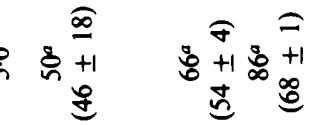

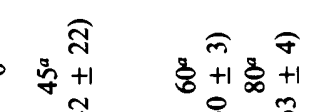

边

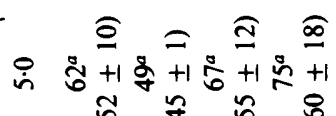

त्र 过

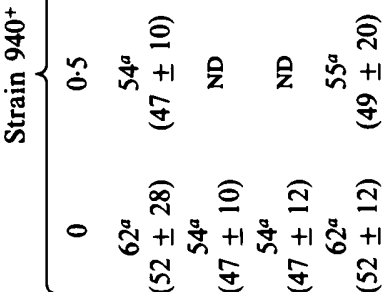

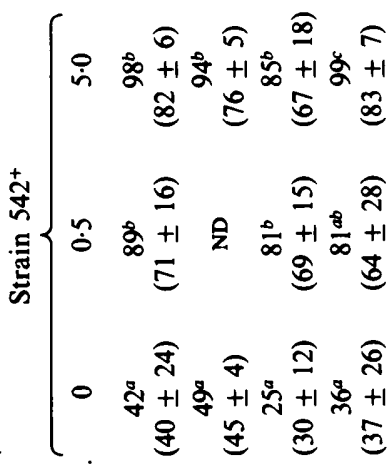

$\frac{i}{E}$

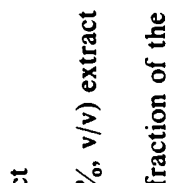

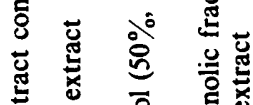

离

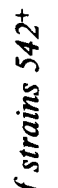

ถั้

$\stackrel{\text { G }}{\circ}$

कू.

కี

范

:

¿

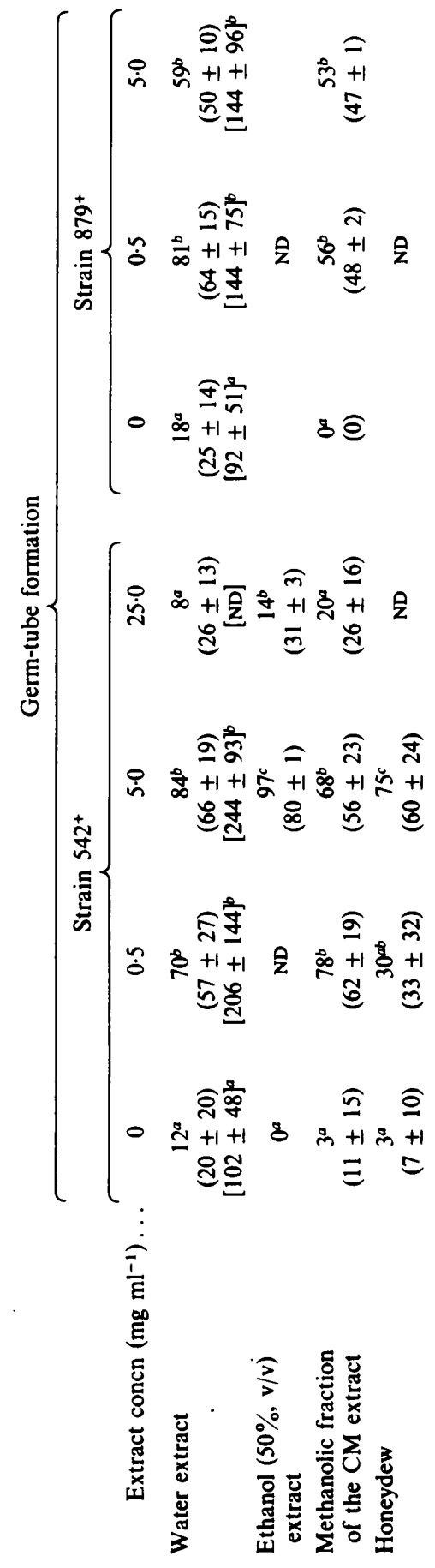


Table 3. Influence of different concentrations of the lipidic extract (chloroform fraction of the chloroform/methanol extract) of the aphid cuticle on the total germination of $C$. obscurus primary spores at pH 6.2 (3 $\pm 1 \mathrm{~h}$ after discharge, depending on the strain)

The results are expressed as in Table 1.

\begin{tabular}{|c|c|c|c|}
\hline \multirow[b]{2}{*}{ Strain } & \multirow{2}{*}{$\begin{array}{l}\text { Extract concn } \\
\left(\mathrm{mg} \mathrm{cm}^{-2}\right) \ldots\end{array}$} & \multicolumn{2}{|c|}{ Total germination } \\
\hline & & 0 & 5 \\
\hline $722^{+}$ & & $\begin{array}{c}48^{a} \\
(29 \pm 6)\end{array}$ & $\begin{array}{c}66^{a} \\
(43 \pm 14)\end{array}$ \\
\hline $879^{+}$ & & $\begin{array}{c}5 \overline{7}^{a} \\
(35 \pm 7)\end{array}$ & $\begin{array}{c}64^{a} \\
\left.\left(40^{ \pm}\right)^{2}\right)\end{array}$ \\
\hline $637^{+}$ & & $\begin{array}{c}36^{a} \\
(22 \pm 17)\end{array}$ & $\begin{array}{c}75^{b} \\
(51 \pm 17)\end{array}$ \\
\hline $940^{+}$ & & $(15 \pm 8)$ & $\begin{array}{c}80^{b} \\
(54 \pm 11)\end{array}$ \\
\hline $313^{-}$ & & $\begin{array}{c}9^{a} \\
(10 \pm 15)\end{array}$ & $\begin{array}{c}51^{b} \\
(35 \pm 14)\end{array}$ \\
\hline $455^{-}$ & & $\begin{array}{c}17^{a} \\
(10 \pm 14)\end{array}$ & $\begin{array}{c}6^{b} \\
(46 \pm 12)\end{array}$ \\
\hline
\end{tabular}

Table 4. Influence of different concentrations of the lipidic extract (chloroform fraction of the chloroform/methanol extract) on the formation of germ-tubes of C. obscurus primary spores $(10 \pm 2 h$ after discharge)

The results are expressed as in Table 1 . All spores of 'strain $879^{+}$produced germ-tubes at $\mathbf{p H} 8 \cdot 0$.

\begin{tabular}{|c|c|c|c|}
\hline \multirow[b]{2}{*}{ Strain } & \multirow{2}{*}{$\begin{array}{l}\text { Extract concn } \\
\left(\mathrm{mg} \mathrm{cm}^{-2}\right)\end{array}$} & \multicolumn{2}{|c|}{ Germ-tube formation at $\mathrm{pH}$ : } \\
\hline & & $6 \cdot 2$ & 8.0 \\
\hline \multirow[t]{2}{*}{$879^{+}$} & 0 & $\begin{array}{c}41^{a} \\
\left(25^{+}+16\right)\end{array}$ & ND \\
\hline & 5.0 & $\begin{array}{c}86^{b} \\
(64 \pm 19)\end{array}$ & ND \\
\hline \multirow[t]{2}{*}{$637^{+}$} & $\begin{array}{c}0 \\
0.5\end{array}$ & $\begin{array}{c}0^{c} \\
14^{b} \\
\left(22^{+}+12\right)\end{array}$ & $\begin{array}{c}0^{c} \\
22^{b} \\
(28+5)\end{array}$ \\
\hline & 5.0 & $\begin{array}{c}65^{a} \\
(53 \pm 7)\end{array}$ & $\begin{array}{c}82^{a} \\
(65 \pm 7)\end{array}$ \\
\hline \multirow[t]{2}{*}{$940^{+}$} & $\begin{array}{c}0 \\
0.5\end{array}$ & $\begin{array}{c}0^{b} \\
61^{a} \\
(51+14)\end{array}$ & $\begin{array}{c}0^{c} \\
31^{b} \\
(34+11)\end{array}$ \\
\hline & 5.0 & $\begin{array}{c}47^{a} \\
(43 \pm 6)\end{array}$ & $\begin{array}{c}92^{a} \\
(73 \pm 3)\end{array}$ \\
\hline
\end{tabular}

Of the six lipidic fractions recovered from preparative TLC only fraction I (hydrocarbon, $R_{F} 0.95$ ) and fraction VI (a very polar material, $R_{F} 0$ ) gave one spot on the thin-layer chromatograms. Fraction II-V indicated four major components, corresponding to alkyl esters, fatty acid methyl esters, free fatty acids and alcohols according to Brey et al. (1985). The use of preparative TLC allowed partial purification of the fractions in the corresponding lipid class but these fractions remained contaminated with one or two other lipid classes. No further purification was undertaken. Lipid fractions were deposited on the agar slides at a dose identical to the concentration of each fraction in a $5 \mathrm{mg} \mathrm{cm}^{-2}$ parent extract stimulatory for germination. Amongst the lipid fractions, the hydrocarbons (fraction I) and polar fraction (fraction VI) induced the formation of germ-tubes of strain $940^{+}$at rates similar to those obtained with the unfractionated extract (Table 5). The stimulation of germ-tube formation by these two fractions 
Table 5. Influence of the different classes of the chloroform extract of the aphid cuticle on the germination of primary spores of strain $940^{+}$of C. obscurus at $\mathrm{pH} 6 \cdot 2$

The results are expressed as in Table 1.

\begin{tabular}{|c|c|c|}
\hline Fraction* & Total germination & $\begin{array}{l}\text { Germ-tube } \\
\text { formation }\end{array}$ \\
\hline I & $\begin{array}{c}47^{a} \\
(43 \pm 25)\end{array}$ & $\begin{array}{c}15^{a b} \\
(23 \pm 15)\end{array}$ \\
\hline II & & \\
\hline III & & \\
\hline $\begin{array}{l}\text { IV } \\
\mathrm{y}\end{array}$ & $\begin{array}{c}2^{b} \\
(8 \pm 16)\end{array}$ & $\begin{array}{c}0^{c} \\
\left(0^{c} \pm 0\right)\end{array}$ \\
\hline VI & & \\
\hline $\begin{array}{l}(\mathrm{I}+\mathrm{II}+\mathrm{III}+\mathrm{IV} \\
+\mathrm{V}+\mathrm{VI})=\mathrm{VII} \\
\text { Unfractionated } \\
\text { extract }\end{array}$ & $\begin{array}{c}\left(48 \frac{ \pm 21)}{9^{b}}\right. \\
(17 \pm 19) \\
81^{a} \\
(64 \pm 23)\end{array}$ & $\begin{array}{c}(17 \pm 11) \\
0^{c} \\
(3 \pm 7) \\
21^{a} \\
(27 \pm 12)\end{array}$ \\
\hline
\end{tabular}

appeared to be specific since they did not modify the total percentage of germination. Fractions II-V strongly inhibited the total germination (Table 5). Subsequent experiments with noninhibitory concentrations $\left(10^{-1}\right.$ dilution) of fractions II-V confirmed that they were not able to provoke the formation of germ-tubes of $940^{+}$spores (data not shown). An intriguing result was the failure of the pooled fractions to stimulate germination, including fractions $\mathrm{I}$ and VI at concentrations promoting the formation of germ-tubes (Table 5).

Stimulation of germination by aphid cuticular extracts appeared specific since strains $940^{+}$ and $637^{+}$did not produce germ-tubes on slides covered by various commercial lipids at 1.0 or $5.0 \mathrm{mg} \mathrm{cm}^{-2}$ (pH 6.2). The lipids tested were fatty acids (myristic, stearic, palmitic and oleic acid), triacylglycerols (trimyristin, tripalmitin, tristearin), alcohols (arachidyl, behenyl, cetyl alcohol and triacontanol), hydrocarbons (heptacosane, tetracosane, triacontane, heneicosane and octacosane), sterols (cholesterol and sitosterol) and complex lipids (lanoline, lanolyl alcohol and sunflower oil).

\section{DISCUSSION}

The results of our studies of the germination of $C$. obscurus spores in vivo (Latge et al., 1982) and in vitro are summarized in Fig. 3. Several conclusions can be drawn from this figure. (1) The proportion of spores forming germ-tubes was higher in vitro than in vivo; a similar conclusion was observed concerning the total germination percentage (Latgé et al., 1982; Sampedro et al., 1984). (2) A few germ-tubes were formed by $\mathrm{A}^{-}$strains in vivo while none were observed in vitro. (3) $\mathrm{A}^{+}$ strains can be separated into two groups: strains $542^{+}$or $722^{+}$(isolated from aphids infected with strain $542^{+}$) and $879^{+}$can be stimulated by water-soluble extracts present on the surface of the aphid cuticle (group $A^{+} 1$ ); strains $940^{+}$and $637^{+}$produce germ-tubes only in the presence of cuticular lipids (group $A^{+} 2$ ). The difference in the in vitro behaviour of these two groups has been previously reported (Sampedro et al., 1984). Germ-tube formation in strains $542^{+}$or $722^{+}$ and $879^{+}$could be induced or stimulated by the addition of salts, sugars and protein hydrolysates to the germination media. It appeared therefore, that low- $M_{\mathrm{r}}$ molecules present on the surface of the aphid cuticle stimulated the germination of these strains. These components probably originate from the honeydew which is rich in free sugars and amino acids (Brey et al., 1985), 


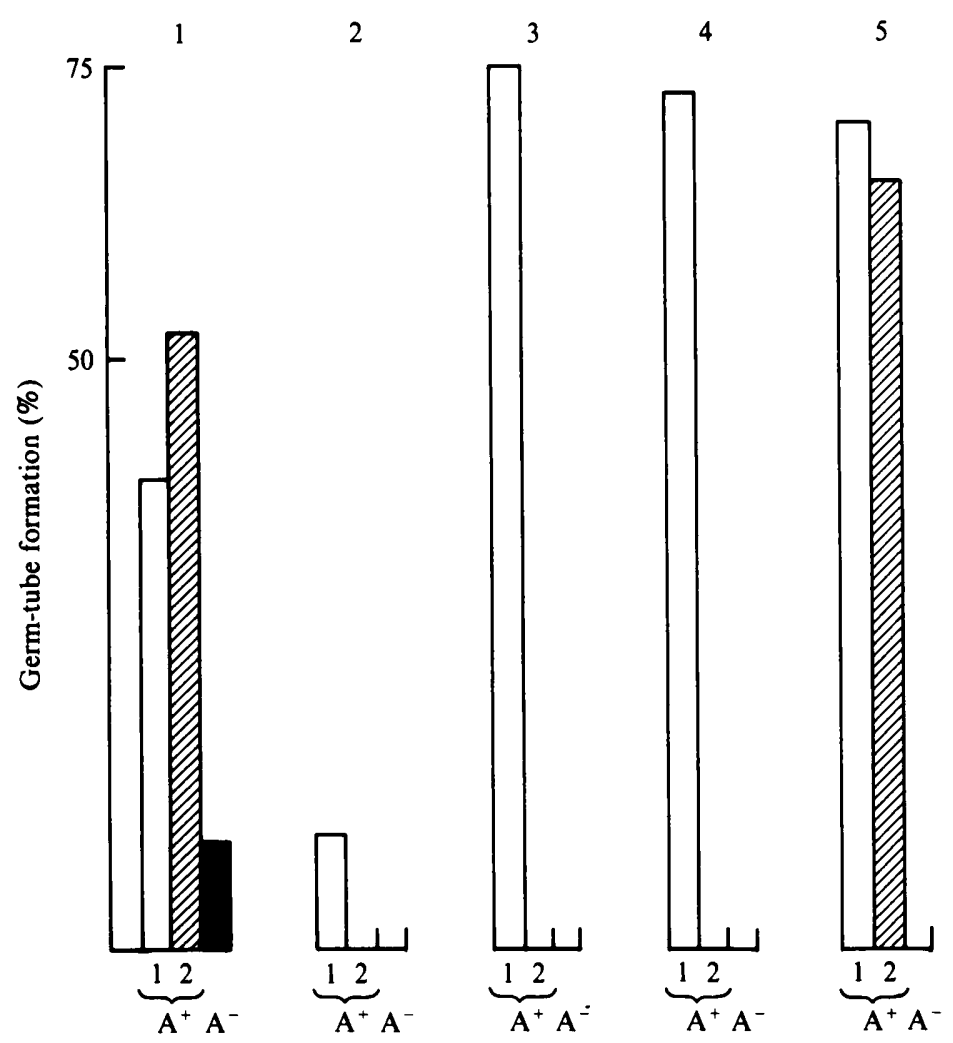

Fig. 3. Schematic histogram representing germ-tube formation by spores of the $A^{+} 1, A^{+} 2$ and $A^{-}$ groups of strains of $C$. obscurus: (1) in vivo on the aphid cuticle; (2) in vitro with no cuticular extract; (3) in vitro in the presence of total polar water- or alcohol-soluble extracts, or in the presence of low- $M_{\mathrm{r}}(500)$ components of the polar extracts; (4) in vitro in the presence of honeydew; (5) in vitro in the presence of total lipid cuticular extracts or in the presence of hydrocarbons of the polar fraction of the lipidic extract.

which stimulated germ-tube formation, but could also come from leaf leachates, cornicular secretions or moulting residues. In contrast, germ-tube production was not induced in vitro with strains of group $\mathrm{A}^{+} 2,940^{+}$and $637^{+}$when water-soluble nutrients were added to the germination medium (Sampedro et al., 1984). This separation between the two groups of $\mathrm{A}^{+}$ strains has also been made on the basis of biological characters (resting spore production) or pathological characters (incubation time of the disease, sporulation capacity of the cadavers) (Latgé et al., 1979; Papierok \& Wilding, 1981). Electrophoretic and serological tests have confirmed the clustering of the $\mathrm{A}^{+}$strains in two groups (Latgé \& Boucias, 1984; Latgé et al., 1986).

Lipids play an important role in the morphological and physiological development of the Entomophthorales. Growth and sporulation of these fungi are stimulated non-specifically by several plant and animal fats (Latgé et al., 1978). The results of the current study demonstrated that the spore development of $\mathrm{A}^{+}$strains of $C$. obscurus could be specifically regulated by the aphid cuticular lipids, particularly by the hydrocarbon and polar fractions. Kerwin $(1982,1984)$ was able to demonstrate that the limitation of Erynia variabilis (Thaxter) Remaudière \& Hennebert to the adult dipteran Fannia canicularis host could be partly due to the cuticular lipids of this insect. Unlike $C$. obscurus, the active fraction in the determination of the specificity of $E$. variabilis for adult dipterans seemed to be the free fatty acid fraction, the presence of sufficient oleic acid inducing the vegetative germination of this species and high levels of palmitoleic acid promoting mycelial growth after germination. 
The influence of cuticular lipids varies according to the insect-entomopathogenic fungus system considered. Boucias \& Pendland (1984) reported that conidial germination of Nomuraea rileyi was stimulated by extracts from Anticarsia gemmatalis, with the sterol and diacylglycerol fractions being the most active. Cuticular extracts from Oryctes rhinoceros and Cetonia aurata, however, did not influence the germination of Metarhizium anisopliae (Fargues, 1981).

Several reports have been made of an antagonistic effect of the cuticular lipids on fungal infection of the insects (Koidsumi, 1957; Evlakhova \& Chekourina, 1962; Smith \& Grula, 1982). This inhibitory effect was attributed in Lepidoptera to short-chain fatty acids such as capric and caprylic acids (Koidsumi, 1957; Smith \& Grula, 1982; Saito \& Aoki, 1984); however, the fatty acids were not tested at concentrations comparable to that present in the epicuticle (Latgé, 1972). Furthermore, short-chain fatty acids are not present in all insect orders and have not been detected in significant amounts in the cuticle of the different Coleoptera and Homoptera studied (J.-P. Latgé, unpublished; Champlin et al., 1981; Brey et al., 1985). In the C. obscurus system, the inhibitory effect of the fatty acid fraction is not due to short-chain fatty acids since Brey et al. (1985) demonstrated that the cuticular lipids of the aphids do not contain short-chain fatty acids. The inhibitory role of these short-chain fatty acids in the resistance of the insects to entomogenous fungi has probably been overestimated.

In $C$. obscurus, the role of the epicuticular lipids appeared quite complex. By pooling all the fractions or by removing the hydrocarbon fraction, the extract became antagonistic. Such intriguing results could indicate that substances both stimulatory and inhibitory to germ-tube formation were present in the same extract. Slight variations in the proportions of the amalgamated fractions may alter germination significantly. Light microscope observations indicated that the morphology of the lipid surface of the pooled fractions was different from the original extract. Fractions II-V displayed the same hairy-crystalline aspect as the pooled fractions whereas fractions I, VI and the crude extract looked more homogeneous (unpublished). Slight modification in the topography of the lipid constituents could affect the water and/or nutrient availability to the spores and consequently influence the germination behaviour of $C$. obscurus spores. Several parasitic fungi are known to be very sensitive to minor differences in host surface topography (Wynn, 1981; Staples et al., 1983).

As for $C$. obscurus, spores of various entomogenous hyphomycetes need water-soluble nutrients on the cuticle of the insects for germination (Fargues, 1981; Boucias \& Pendland, 1984; Woods \& Grula, 1984). Amino acids and glucosamine seemed the most effective polar components (Kerwin, 1982; Boucias \& Pendland, 1984; Sampedro et al., 1984; Woods \& Grula, 1984). Water-soluble extracts can also have a negative effect on the germination of entomogenous fungi. Ethanolic extracts from a pink clone of $A$. pisum resistant to $C$. obscurus infection inhibited the germination of $\mathrm{A}^{+}$strains of this species (J.-P. Latgé, unpublished). Water-soluble cuticular phenols inhibit the mycelial growth of Aphanomyces astaci (Ajaxon \& Söderhäll, 1982) and conidial development of Cordyceps militaris (J.-P. Latgé, unpublished). Phytopathogenic fungi can be similarly stimulated or inhibited by water leachates from plants (Godfrey, 1976; Wildman \& Parkinson, 1981 ; Kaminskyj \& Day, 1984). As in plant pathogens (Matta, 1982), the saprophytic microflora associated with free nutrients present on the cuticular surface of the insect could also influence the pathogenesis of entomogenous fungi. The presence of fungal and bacterial contaminants on the beetle Hylobius pales inhibited the germination of the conidia of $M$. anisopliae (Schabel, 1978). The microflora of the pea aphid (about 3.106 bacteria per aphid, mainly Gram-positive cocci), when tested in vitro, was ineffective against the $722^{+}$strain group but could inhibit the germination of the $940^{+}$type strain (A. Uziel \& J.-P. Latgé, unpublished).

The influence of the cuticular extracts is highly dependent on their concentration. The concentration of the lipid extract has been roughly estimated as $0.2-0.5 \mathrm{mg}$ per $\mathrm{cm}^{2}$ of aphid cuticle (10-20 mg lipid per $\mathrm{g}$ of fresh aphids, corresponding to a volume of aphids of $5 \mathrm{~cm}^{3}$ ). Lipid concentrations less than the cuticular doses will not induce germ-tube formation. Doses 510 times greater than the cuticular concentration still induced the formation of germ-tubes. Similarly, the concentration of polar components was about 4-8 $\mu \mathrm{g} \mathrm{cm}^{-2} \mu \mathrm{m}^{-1}(5-10 \mathrm{mg}$ extract per $5 \mathrm{~cm}^{3}$ of aphids, calculation based on the $50 \mu \mathrm{m}$ outer-layer). The doses tested which induced 
the formation of the germ-tubes were between 1 and $20 \mu \mathrm{g} \mathrm{cm}^{-2} \mu \mathrm{m}^{-1}$. A concentration of $0.1 \mu \mathrm{g} \mathrm{cm}^{-2} \mu \mathrm{m}^{-1}$ failed to enhance the formation of germ-tubes (data not shown). These results stress the necessity of using a concentration of cuticular extracts similar to those encountered in the cuticle in in vitro germination tests of entomopathogenic fungi.

The influence of the cuticular components on the behaviour of entomogenous fungi has always been tested with fractions extracted from non-infected whole insects however, components secreted by the insect in response to the recognition of the fungal pathogen and arriving at the surface of the cuticle through the pore canals could also influence the germination of the spores. Such components, induced in plants by phytopathogenic fungi (Roberts \& Aist, 1984), have not been identified in entomopathogenic fungal systems. A role of cuticular monomers released by exocellular enzymes has been suggested in the pathogenesis of $C$. obscurus and Beauveria bassiana (Latgé et al., 1984; Woods \& Grula, 1984).

The difference in the germination behaviour of the two groups of $\mathrm{A}^{+}$strains could have an ecological or epidemiological significance. In low-density aphid populations, aphids are rarely in contact and their cuticles would rarely be contaminated with honeydew. This would result in very limited development of the saprophytic microflora. In these conditions, strains of the $940^{+}$ group, stimulated by the cuticular lipids, have the highest chances of infecting an insect. The persistence of these strains in low-density aphid populations would be favoured by their high sporulating capacity (Papierok \& Wilding, 1981), increasing the chance of contact between the discharged conidia and the scarce aphids. In heavy insect populations, aphids are constantly in close contact and their cuticles would be readily covered by the honeydew (stimulating the $722^{+}$ group) and its associated saprophytic flora (inhibiting the $940^{+}$group). In consequence, strains of the $722^{+}$group would preferentially infect the aphids. The complete destruction of the aphid population would be accelerated by the fast killing action of this group of $C$. obscurus strains.

In addition, these strains have the highest capacity for resting spore formation in the aphid body under various environmental conditions (Papierok \& Latgé, 1980). The eradication of the aphid population would be then accompanied by the presence of numerous cadavers filled with resting spores that would facilitate the persistence of the fungus in the absence of aphids until the subsequent breeding season (Latgé et al., 1979).

We are indebted to D. Boucias, J. L. Kerwin and N. Wilding for providing valuable suggestions and English corrections.

\section{REFERENCES}

AJAXON, R. \& SöDERHälL, K. (1982). Effect of quinones and melanin on mycelial growth of Aphanomyces spp. and extracellular protease of Aphanomyces astaci a parasite on crayfish. Journal of Invertebrate Pathology 39, 105-109.

Baker, J. E., SukKestad, D. R., Nelson, D. R. \& Fatland, C. L. (1979). Cuticular lipids of larvae and adults of the cigarette beetle, Lasioderma serricorne. Insect Biochemistry 9, 603-611.

Boucias, D. G. \& Pendland, J. C. (1984). Nutritional requirements for conidial germination of several host range pathotypes of the entomopathogenic fungus Nomuraea rileyi. Journal of Invertebrate Pathology 43, 288-292.

Brey, P. T., Ohayon, H., Lesourd, M., Castex, H., Roucache, J. \& LATGÉ, J. P. (1985). Ultrastructure and chemical composition of the outer layers of the cuticle of the pea aphid Acyrthosiphon pisum (Harris). Comparative Biochemistry and Physiology A82, 401411.

Champlin, F. R., Cheung, P. Y. K., Pekrul, S., Smith, R. J., Burton, R. L. \& Grula, E. A. (1981). Virulence of Beauveria bassiana mutants of the pecan weevil. Journal of Economic Entomology 74, 617621.
Cole, G. T. \& NozaWA, Y. (1981). Dimorphism. In Biology of Conidial Fungi, vol. 1, pp. 97-133. Edited by G. T. Cole \& B. Kendrick. New York: Academic Press.

Evlakhova, A. A. \& Chekourina, T. A. (1962). L'activité de défense de la cuticule de la punaise des céréales (Eurygaster integriceps Put.) contre les microorganismes végétaux. Colloque international de pathologie des insectes, Entomophaga. Mémoires hors série 12, 137-141.

FARGUES, J. (1981). Spécificité des hyphomycètes entomopathogènes et résistance interspécifique des larves d'insectes. Thèse de Doctorat d'Etat, Université de Paris VI.

GODFREY, B. E. S. (1976). Leachates from aerial parts of plants and their relation to plant surface microbial populations. In Microbiology of Aerial Plant Surfaces, pp. 433-439. Edited by C. H. Dickinson \& T. F. Preece. London \& New York: Academic Press.

GoTTliEB, D. (1978). The Germination of Fungus Spores. Durham: Meadowfield Press.

Kaminskyj, S. G. W. \& DAY, A. W. (1984). Chemical induction of infection structures in rust fungi. $I$. Sugars and complex media. Experimental Mycology 8, 63-72. 
KeRWIN, J. L. (1982). Chemical control of the germination of asexual spores of Entomophthora culicis, a fungus parasitic on dipterans. Journal of General Microbiology 128, 2179-2186.

KERWIN J. L. (1984). Fatty acid regulation of the germination of Erynia variabilis conidia on adults and puparia of the lesser housefly, Fannia canicularis. Canadian Journal of Microbiology 30, 158-161.

KoIDsumI, K. (1957). Antifungal action of cuticular lipids in insects. Journal of Insect Physiology 1, 40-51.

Latgé, J.-P. (1972). Contribution à l'étude du Cordyceps militaris (Fr.) Link. Systématique, biologie, physiologie. Doctorat de spécialité, Université de Toulouse.

LATGÉ, J.-P. \& Boucias, D. (1984). Intraspecific variability in Conidiobolus obscurus. Journal of General and Applied Microbiology 30, 135-150.

Latgé, J.-P., Remaudiere, G. \& Diaquin, M. (1978). Un nouveau milieu pour la croissance des champignons entomophthorales pathogènes d'aphides. Annales de Microbiologie B129, 463-476.

Latgé, J.-P., Perry, D. F., Papierok, B., CoremansPelseneer, J., Remaudiere, G. \& Reisinger, $O$. (1979). Induction de la formation des spores de résistance d'Entomophthora obscura Hall \& Dunn. Comptes rendus hebdomadaires de séances de l'Académie des Sciences D288, 599-602.

Latgé, J.-P., Papierok, B. \& Sampedro, L. (1982). Agressivité de Conidiobolus obscurus vis-à-vis du puceron du pois. I. Comportement des conidies sur la cuticule avant la pénétration du tube germinatif dans l'insecte. Entomophaga 27, 323-330.

LATGÉ, J.-P., SAMPEDRo, L. \& Hall, R. (1984). Agressivité de Conidiobolus obscurus vis-à-vis du puceron du pois. III. Activités enzymatiques exocellulaires. Entomophaga 29, 185-201.

LATGÉ, J.-P., SAMPEDRo, L. \& Boucias, D. (1986). Aggressiveness of Conidiobolus obscurus against the pea aphid. IV. Electrophoretical and immunoelectrophoretical characterization of aggressive strains. Journal of Invertebrate Pathology 48, 159-166.

MATTA, A. (1982). Mechanisms in non-host resistance. In Active Defense Mechanisms in Plants, pp. 119-141. Edited by R. K. S. Wood. New York: Plenum Press.

PAPIEROK, B. \& LATGÉ, J.-P. (1980). Considérations sur le pouvoir pathogène de Entomophthora obscura Hall $\&$ Dunn à l'égard des pucerons des céréales. Bulletin OILB/SROP III, 4, 27-29.

PAPIEROK, B. \& WILDING, N. (1979). Mise en évidence d'une différence de sensibilité entre 2 clones du puceron du pois Acyrthosiphon pisum Harr. (Homoptère, Aphididae) exposés à 2 souches du champignon Phycomycète Entomophthora obscura Hall \& Dunn. Comptes rendus hebdomadaires de l'Académie des Sciences 288D, 93-95.

PAPIEROK, B. \& WILDING, N. (1981). Etude du comportement de plusieurs souches de Conidiobolus obscurus (Zygomycètes Entomophthoraceae) vis-à-vis des pucerons Acyrthosiphon pisum et Sitobion avenae (Hom.: Aphididae). Entomophaga 26, 241-249.

ROBERTS, D. W. \& AIST, J. R. (editors) (1984). Infection Processes of Fungi (a Bellagio conference in March 1983). New York: The Rockefeller Foundation.

SAITO, T. \& AOKI, J. (1984). Toxicity of free fatty acids on the larval surface of two lepidopterous insects towards Beauveria bassiana (Bals.) Vuill. and Paecilomyces famoso-roseus (Wize) Brown et Smith (Deuteromycetes: Moniliales). Applied Entomology and Zoology 18, 225-233.

SAMpedro, L., Uziel, A. \& Latgé, J.-P. (1984). Agressivité de Conidiobolus obscurus vis-à-vis du puceron du pois. II. Mode de germination in vitro des conidies primaires de souches d'agressivité différente. Mycopathologia 86, 3-19.

SCHABEL, H. G. (1978). Percutaneous infection of Hylobius pales by Metarhizium anisopliae. Journal of Invertebrate Pathology 31, 180-187.

SMITH, R. J. \& GrULA, E. A. (1982). Toxic components on the larval surface of the corn earworm (Heliothis $z e a)$ and their effects on germination of Beauveria bassiana. Journal of Invertebrate Pathology 39, 15-22.

Staples, R. C., GRAmbow, H. J. \& HoCh, H. C. (1983). Potassium ion induces rust fungi to develop infection structures. Experimental Mycology 7, 40-46.

WILdMan, H. G. \& PARKInson, D. (1981). Comparison of germination of Cladosporium herbarum and Botrytis cinerea conidia in vitro in relation to nutrient conditions on leaf surfaces. Canadian Journal of Botany 59, 854-861.

Woods, S. P. \& Grula, E. A. (1984). Utilizable nutrients on Heliothis zea available for growth of Beauveria bassiana. Journal of Invertebrate Pathology 43, 259-269.

WYNN, W. K. (1981). Tropic and toxic responses of pathogens to plants. Annual Review of Phytopathology 19, 237-255. 